\title{
Effect of Concept Mapping in Teachng of Physics in Senior Secondary Schools in Portharcourt Local Government Area Rivers State
}

\author{
Omeodu M. Doris \\ Department of Science Education, \\ Rivers State University, Port Harcourt, Nigeria
}

Doi:10.19044/esj.2018.v14n31p71 URL:http://dx.doi.org/10.19044/esj.2018.v14n31p71

\begin{abstract}
The study examined the effect of concept mapping in the teaching of physic in senior secondary school in port Harcourt local government area Rivers state. The purpose of the study was to determine the effect of concept mapping on the teaching of physics. The study also found the difference in the academic achievement of students taught physics with concept mapping and conventional teaching method. Eighty-four SS3 physics students were used for the study. Forty-three 43 comprised of the experimental group and fortyone in the control group. The study adopted pre-test post test quasi experimental design. The instrument used for the study was Physics achievement test (PAT).The instrument contained 25 multiple choice questions, in which each of the questions 2 marks. The instrument was validated by two experts in the department of science education in Rivers State University. Pearson product moment correlation coefficient was used to ascertain the instrument's level of reliability, which resulted to $r$ value of 0.62 . findings of the study shows that students taught Physics with concept mapping significantly better than those taught with conventional method. Also the study found that there was no significant difference between male and female students taught Physics with concept mapping. The study recommended that teachers should imbibe concept mapping method in the teaching of Physics so as to enhance students' comprehension, identification of relationships that exits between concepts and creativity.
\end{abstract}

Keywords: Concept, Mapping, Effects, Achievement, Physics.

\section{INTRODUCTION.}

There is a growing concern in all parts of the nation over a decline in the quantity of students who enroll in physics courses in Nigeria tertiary institutions. This decline has been accorded to the students' poor performance 
in senior secondary certificate examination (Gungor, Eryilmaz, and Fakioulu 2007) The annual Waec chief examiners report (2001-2014) has it that there is an increase in students' failure of practical examination and Physics is not excluded. In the findings of Eniayeju (2010) students attributes underachievement in science subjects to the way science courses are taught in classes. Also researchers have discovered that teaching method is one of the major factors that determine students attitudes and achievement in Physics. It was found that physics students perceived that many concepts in physics are abstract in nature hereby making learning relatively difficult. Due to this cause, Gbamaja (1999) pointed that content, methodology, and techniques are some of the basic element of teaching and concluded that good teaching requires sound and deep knowledge of pedagogical principles of conveying that knowledge to the learners.

However, Nzewi (2008) asserted that diverse strategies of teaching have been proposed so as to improve student understanding of science subject such strategies include the use of analogy, co-operative learning, inquiry, concept of advance organizer and concept mapping instructional strategies. Several literature has proposed that concept mapping helps student to understand interrelationship among concepts, predict, observe, and explain science subjects to improve students' understanding of abstract terms (Jacobson, 2013).

Torre and Daley (2007) affirmed in their study that concept mapping takes into account innovativeness by building up an arrangement of reasoning that included the capacity to think comprehensively on themes and considered learning in corporation. A concept map is a teaching approach in secondary schools which gives exact data about the information areas considered. Concept mapping strategies of science enables students to reason through an issue or topical issue by imagining the communications between contention, concepts, subject and proof.

Concept mapping strategy of teaching was originally by Novak and his research group as a means of representing framework to show interrelationships that exist between concepts Novak and Gowin (1996). Maduabum (2002) described concept mapping teaching approach as a graphical arrangement of key concepts to show meaningful relationship among selection of concepts or concepts being studied. In other terms, concept mapping involve a representation that shows explicit relationship between concepts using linking words between concepts and arranging the concepts expressed in hierarchical form. It is a visual representation of what students' see as relationship between particular concepts. These concepts are connected using lines and arrows to indicate relationship between concepts understudy.

Concept mapping enables learners;

- conceptualize and construct new thoughts 
- to find new concepts and the recommendation

- to coordinate new concepts with more ones

- to increase upgraded learning of any point and assess data.

According to Novak and Gowin (1996) concept mapping serves as a tool to help learners organize their cognitive strategy which assist the learners in seeing hierarchical conceptual prepositional nature of knowledge. This indicates that the organization of the cognitive process in learning a concept creates a meaningful learning, understanding and enhances memory in the learner. Concept mapping teaching approach likewise constitute fascinating asset to help the learning procedures of reasonable substance regardless of whether inside a structure of independent learning exercises or with the assistance of the educator. Soares and Voldares (2006) opined that concept mapping can become an excellent process of integrating knowledge in a social environment which is cooperative and constructivist. They added that concept mapping are excellent tools for formative evaluation in the learner, that is students' early conception hence enabling them identify relationships and new meaning. Jonne and george (2009) opined that concept mapping is a student centered teaching approach that enforces learner to engage in critical thinking about the relationship that exist between concepts. It supports the theory of meaningful learning of Ausbel (1968) which holds that students are not to be lot of information in which they lack proper understanding rather meaningful learning should involve creation and development of own knowledge in an active process. Concept mapping presents information in a less complex but interconnected manner which discredits rote learning.

\section{How to draw a concept map}

Drawing a concept map does not require a unidirectional approach. It could be made in different forms for the same set of concepts. There is no way draw a concept, it is based on understanding of relationships that exists between concepts. Change in concept map is directly proportional to understanding relationships between concepts. According to Novak (1988) Below is the step by step procedure of how to draw a concept map;

Step 1; Identify 10-20 concepts that are significant in the topic intending to teach

Step 2; concept ranking. This concepts are ranked based o how broad they are. The broadest concepts are placed on the top of the map.

Step 3; place the one, two, three or four concept general concept at the top of the map.

Step 4; Select two, three or four sub-concepts that are related to each of the general concepts on top of the map and place them under them. In a situation whereby many concepts belong to one major concept or sub-concept, creation of another level of hierarchy of intermediate inclusiveness is allowed. 
Step 5; show the interrelationship between concepts using arrows or lines and few linking words.

Step 6; Review the map to substitute, add, subtract or change superordinate concepts. This process may be done several times to ensure constructive mapping.

Step 7; look for crosslinks between concepts in different sections of the map and label these lines. This helps the learners to identify creative relationship between concepts. Crosslinks suggests that related broad concepts should not be placed far from one another. Figure1.1 is a typical diagram of a concept map in energy

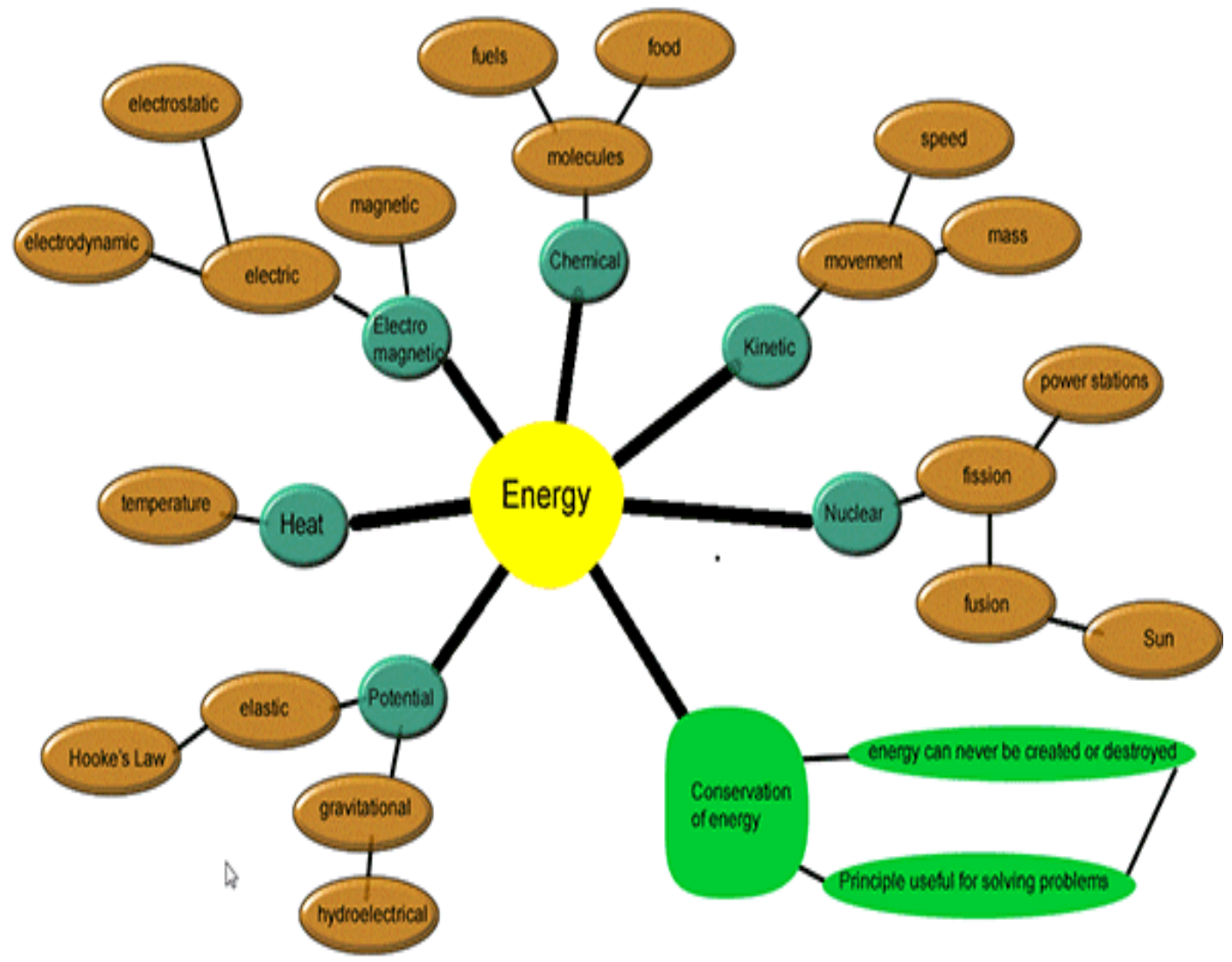

Fig 1.1 Source; Ricardo (2018)

\section{Purpose of the study}

The purpose of the study is to examine the effect of concept mapping on the achievement of physics students. Specifically, the study sought to:

1. Determine the academic achievement of students taught with concept mapping using the pre-test and post test scores. 
2. Determine the difference in the academic achievement of students taught with concept mapping and conventional teaching method.

3. Determine the mean difference that exist between the academic achievement of male and female students taught with concept mapping method

\section{Research questions}

1 What is the academic achievement of students taught with concept mapping using the pre-test and post test scores.

2 What is the difference in the academic achievement of students taught with concept mapping and conventional teaching method.

3 What is the mean difference that exist between the academic achievement of male and female students taught with concept mapping method

\section{Hypothesis}

The following hypothesis were tested at 0.05 level of significance

- There is no significant difference between the pretest mean scores of students taught physics in both experimental group and control group.

- There is no significant different in the academic achievement of students taught physics with concept mapping and conventional mode of instruction

- There is no significant difference in the academic achievement of male and female students taught physics with concept mapping teaching method

\section{Methodology}

The study adopted pre-test post test quasi experiment design. The study included experimental and control groups so as to determine the effect of concept mapping on student academic achievement in physics over other conventional method of teaching.

Quasi experimental design study

\begin{tabular}{llll}
\hline & Pretest & Treatment & Post-test \\
\hline Experimental group & $0_{1}$ & $\mathrm{X}$ & $0_{2}$ \\
Control group & $0_{3}$ & - & $0_{4}$ \\
\hline
\end{tabular}

$0_{1-}$ Pretest performance of experimental group

$\mathrm{O}_{2}$ - Post test performance of experimental group

$\mathrm{O}_{3}$ - Pretest performance of control group

$0_{4}$ - Post test performance of control group

$\mathrm{x}$ - Treatment (concept mapping)

The population of the study comprised of all secondary school physic students in Port Harcourt local government area Rivers State. Simple random 
sampling was used to select two senior secondary schools in Port Harcourt local government area which was used for the study. There were 46 physics students in one school, that is, 23 in SS3A and 23 in SS3B. In the other school there were 39 physics students, that is, 20 students in SS3A and 19 in SS3B. For the purpose of this study the researcher grouped SS3A students in both schools (43 students) as experimental group while SS3B students in both schools (41 students) were used as the control group.

The instrument used for collecting data was Physics Achievement Test (PAT). PAT was constructed based on all concepts that students were taught by the researcher. The instrument consisted of 25 multiple choice questions which was developed to assess students'

- level of comprehension of concepts

- level of identifying relationship between concepts

- Create new thoughts and ideas.

Each question carries two marks. The instrument was validated by two experts from the department of science education, Rivers State University. The reliability of the instrument was tested using Pearson Product Moment Correlation Coefficient (PPMC) which yielded 0.62 reliability coefficient. The researcher taught the both experimental and control group on different occasions and EAT was administered immediately after teaching each of the groups by the researcher and other assistants. Mean and standard deviation was used to answer the research questions and z-test and ANCOVA was used to test the hypothesis at 0.05 level of significance.

\section{Analysis and discussion of findings Research question 1}

What is the academic achievement of students taught with concept mapping using the pre-test and post test scores?

Table 1: Academic achievement of students taught physics using concept mapping

\begin{tabular}{lllllll}
\hline Group & \multicolumn{2}{l}{ Pre-Test } & \multicolumn{3}{c}{ Post test } & $\begin{array}{l}\text { Mean } \\
\text { difference }\end{array}$ \\
& No & Mean & S.D & Mean & S.D & \\
\hline $\begin{array}{l}\text { Experimental } \\
\text { Group }\end{array}$ & 43 & 16.65 & 5.05 & 33.16 & 6.24 & 16.51
\end{tabular}

Source: Field survey

Table 4.1 revealed that the pre-test mean score of the group taught with concept mapping is 16.65 , while the post-test means score was 33.16 . In the experimental group, the post-test mean score is greater than the pre-test scores with the mean difference of 16.51. Students increased almost twice their formal knowledge due to the mode of instruction. 


\section{Research question 2:}

What is the difference in the academic achievement of students taught with concept mapping and conventional teaching method

Table 2: difference in the academic achievement of students taught with concept mapping and conventional teaching method

\begin{tabular}{|c|c|c|c|c|c|c|}
\hline \multirow[t]{2}{*}{ Group } & \multicolumn{3}{|c|}{ Pre-Test } & \multicolumn{2}{|c|}{ Post test } & \multirow{2}{*}{$\begin{array}{l}\text { Mean } \\
\text { difference }\end{array}$} \\
\hline & No & Mean & S.D & Mean & S.D & \\
\hline $\begin{array}{l}\text { Experimental } \\
\text { Group }\end{array}$ & 43 & 16.65 & 5.05 & 33.16 & 6.24 & 16.51 \\
\hline $\begin{array}{l}\text { Control Group } \\
\text { Differences }\end{array}$ & 41 & $\begin{array}{l}16.08 \\
0.57 \\
\end{array}$ & 4.05 & $\begin{array}{l}21.03 \\
12.13 \\
\end{array}$ & 5.96 & $\begin{array}{l}4.95 \\
11.56 \\
\end{array}$ \\
\hline
\end{tabular}

Source: Field Survey, 2018.

Table 4.2 revealed that the experimental group has the pretest mean scores of 16.65 and post test mean scores was 33.16 with the mean difference of 16.51. Whereas the pretest scores of the control group taught with conventional method was 16.08 and post test mean scores of 21.03 with the mean difference of 4.95. Also, the difference that exists between the pretest and post test difference of both groups was 11.56. In other to ensure that the result was not contaminated by prior knowledge a pretest which was conducted between the two groups shows a very low portion of 2.44. It is therefore vivid that concept mapping mode of instruction enhanced students' performance more than the conventional teaching method. This finding is in conformity with the findings of Ahmad and Munawar (2013) who affirmed that male and female students that were taught elementary science performed significantly better than those who were taught with traditional teaching method.

\section{Research question 3:}

What is the mean difference that exist between the academic achievement of male and female students taught with concept mapping method

Table 3: Mean difference that exists between the academic achievement of male and female students taught with concept mapping method.

\begin{tabular}{lllll}
\hline Group & No & Post-test & & $\begin{array}{l}\text { Mean } \\
\text { difference }\end{array}$ \\
\hline & & Mean & S.D & 0.68 \\
Male EG & 18 & $\mathbf{3 3 . 5 6}$ & $\mathbf{5 . 5 9}$ & \\
Female EG & $\mathbf{2 5}$ & $\mathbf{3 2 . 8 8}$ & $\mathbf{6 . 8 8}$ & \\
\hline
\end{tabular}

Source: Field survey. EG- experimental group

Table 3 presents the gender performance of the experimental group, this is to find out whether concept mapping mode of instruction is gender sensitive. Male students had a mean score of 33.56 and female students had a mean score of 32.88. The mean difference that exist between both performances is 0.68 . The findings of Osisioma (1995) affirmed that gender 
was found not to exert any significant influence on the attitudes and achievement of students in integrated science. There was no significant difference between the achievement of male and female students taught integrated science during the study. However, the findings of Ahmad and Munawar (2013) showed that male students performed better than the female students. In the current findings there is a difference of 0.68 between the post test scores of male and female students, which is in favour of the male students. This mean difference will be subjected to hypothesis to determine its significance

\section{Hypothesis}

H01: There is no significant difference between the pretest mean scores of students taught physics in both experimental group and control group.

Table 4: z-test analysis on the difference between the pretest mean scores of students taught physics in both experimental group and control group.

\begin{tabular}{llllllll}
\hline Groups & Mean & S.D & N & $\begin{array}{l}\text { Lev. Of } \\
\text { sig. }\end{array}$ & z-cal & z.crit & Decision \\
\hline $\begin{array}{l}\text { Concept } \\
\text { mapping }\end{array}$ & 16.65 & 5.05 & 43 & & & & \\
$\begin{array}{l}\text { Lecture } \\
\text { method }\end{array}$ & 16.08 & 4.05 & 41 & 0.05 & 0.57 & 1.96 & NS \\
\hline
\end{tabular}

Source; Field Survey, 2018. NS- not significant

Table 4 presents the z-test analysis on the pre test mean scores of students in the experimental and the control group. The mean scores of the pre test was done to ascertain that both groups have equivalent level of prior knowledge before the experiment was conducted. However, the z-test conducted on both means yielded a Z-cal value of 0.57 which is less than the $\mathrm{z}$-critical value of 1.96 . Therefore the hypothesis is rejected. This signifies that the difference that exist between the pretest scores of both groups is insignificant. So the experiment was conducted on a balanced scale.

$\mathrm{H}_{02}$ : There is no significant different in the academic achievement of students taught physics with concept mapping and conventional mode of instruction.

Table 4; z-test analysis on the academic achievement of students taught physics with concept mapping method and lecture method

\begin{tabular}{lccccccc}
\hline Groups & Mean & S.D & N & $\begin{array}{l}\text { Lev. Of } \\
\text { sig. }\end{array}$ & z-cal & z.crit & Decision \\
\hline $\begin{array}{l}\text { Concept } \\
\text { mapping }\end{array}$ & 33.16 & 6.24 & 43 & & & & \\
$\begin{array}{l}\text { Lecture } \\
\text { method }\end{array}$ & 21.03 & 5.96 & 41 & 0.05 & 9.10 & 1.96 & S \\
\hline
\end{tabular}

Source; Field Survey, 2018. NS- not significant 
Table 4 presents the z-test analysis on the academic achievement of students taught physics with concept mapping and conventional mode of instruction. The table shows that the $\mathrm{z}$-calculated (9.10) is greater than the $\mathrm{z}$ crit (1.96). Therefore, the hypothesis which states that there is no significant different in the academic achievement of students taught physics with concept mapping and conventional mode of instruction is rejected. That is, students who were taught physics with concept mapping method performed better than those who were taught with conventional method of teaching.

$\mathrm{H}_{03}$ : There is no significant difference in the academic achievement of male and female students taught physics with concept mapping teaching method.

Table 5: z-test analysis on the academic achievement of male and female students taught physics with concept mapping teaching method.

\begin{tabular}{lccccccc}
\hline Groups & Mean & S.D & N & $\begin{array}{l}\text { Lev. Of } \\
\text { sig. }\end{array}$ & z-cal & z.crit & Decision \\
\hline Male & 33.56 & 5.59 & 18 & 0.05 & 0.35 & 1.96 & NS \\
Female & 32.88 & 6.88 & 25 & & & & \\
\hline
\end{tabular}

Source; Field Survey, 2018. NS- not significant

Table 5 shows the z-test analysis on the academic achievement of male and female students taught physics with concept mapping teaching method. It was revealed that there is no significant different between the post test mean scores of male and female students taught Physics with concept mapping method. The difference that exists in the mean scores of male and female students was not significant. This is to say that concept mapping method is not gender sensitive; it generally accommodates the level and learning styles of all students based on gender.

\section{Conclusion}

Based on the findings of the study, the following conclusions were made;

- Concept mapping method of teaching increases student achievement almost twice their prior knowledge.

- Students taught physics with concept mapping mode of instruction performed significantly better that those taught with conventional modes

- Concept mapping teaching method is not gender sensitive. It aligns with gender differences and learning styles. Although male mean scores was higher than the females but the difference was not statistically significant 


\section{Recommendation} the study;

The following recommendations were made based on the findings of

- Science teachers should imbibe concept mapping teaching methods in the teaching of science subjects so as to enhance comprehension, identification relationship between concepts and creativity.

- Science teachers should engage concept mapping to actively involve the students in identifying relationships in concepts

- Students should be encouraged to draw a map of concepts of topic being taught after teaching.

\section{References:}

1. Ahmad B. C, Munawar S. M. (2013). Effect of Concept Mapping On Students' Academic Achievement. Journal of Research and Reflections in Education.vol.7, No.2, pp 125 -132

2. Ausbel, D.P., (1968). Education Psychology: A cognitive Review, New York: Holt, Rinehart and Winston Inc.

3. Eniayeju, P. (2010). Where is the STEM? Reflections on the Missing Context in Science, Technology, Engineering and Mathematics Instruction. 51 Annual conference of STAN proceedings 3-15.

4. Gbamaja, S.P.T. (1999). Modern Methods in Science Education in Africa. Totan Publishers Port Harcourt.

5. Gungor, A., Eryilmaz, A. and Fakioulu, T. (2007) 'The Relationship of Freshmen's Physics Achievement and their Related Affective Characteristics'. Journal of Research in Science Teaching, 44(8), 10361056.

6. Joanne, B. and George. M, (2009). Integrating Concept Mapping into Higher Education: A Case study with Physics Education Students in an Irish University. British Education Research Association (BERA) Conference 2009.

7. Maduabum, M.A. (2002). Teaching Biology Effective, $2^{\text {nd }}$ Edition, Owerri: White and Whyte Publishers.

8. Novak J.D (1988). Learning, creating and using knowledge; concepts maps as facilitative tools in schools and co-operation; Mawah N.J Lawrence Erlbaum Associates, INC

9. Novak, J.D. and Godwin, D.B. (1996). Learning How to Learn. New York Cambridge University Press.

10. Nzewi,U.M.(2008). Practical Approach to the Effective Teaching of Ecological Concept of Sustainable Development. An Address Presented at STAN Biological Panel National Workshop Held at Queens Secondary Schools, Enugu. 
11. Osisioma, I.U. (1995) Effect of Concept Mapping and Gender on Student Achievement and Attitudes Towards Integrated Science. University of Nigeria research publications $(U N N)$.

12. Ricardo, E. (2018). Concept maps index. Brighton tuition, past paper revision. Also available online at www.sci-culture.com/concept-mapsindex.html

13. Soares, M. T. and Valadares, J (2006). Using Concept Maps as a Strategy to Teach Physics, in Particular the Topic of Acoustics. Concept Maps: Theory, Methodology, Technology Proc. of the Second Int. Conference on Concept Mapping A. J. Cañas, J. D. Novak, Eds. San José, Costa Rica, 2006

14. Torre, D.M. and Daley, B.J. (2007). Qualitative Evaluation of Medical Students Learning with Concept Maps. Med Teach p:29:94955 